\title{
A PANCREATIC TUMOUR SECRETING GROWTH HORMONE-RELEASING HORMONE (GHRH) CAUSING ACROMEGALY, ASSOCIATED WITH A MEDIASTINAL PARAGANGLIOMA
}

\author{
G Subramanian, SpR, J Goldman, Consultant, Chest Medicine; NJK Crook, SpR, \\ RB Paisey, Consultant, Endocrinology; NG Ryley, Consultant, \\ T Alderson, Consultant, Histopathology, Torbay Hospital
}

\section{CASE REPORT}

A 64-year-old retired plumber was referred to the respiratory department for investigation of a three-year history of snoring and more recent daytime somnolence and poor concentration. His Epworth score was 15, consistent with the diagnosis of obstructive sleep apnoea, which was confirmed on sleep study and successfully treated with overnight continuous positive airway pressure ventilation. At presentation, mild acromegalic features were noted in the presence of normal visual fields and his IGF1 was elevated at $46.5 \mathrm{nmol} / \mathrm{l}$ (5-22.5) supporting a diagnosis of active acromegaly. Chest radiograph showed a mass behind the right hilum and thoracic computed tomography (CT) confirmed a large soft tissue mass in the superior mediastinum between superior vena cave and trachea. Tissue obtained by video assisted thoracoscopy displayed features of a paraganglioma. The possibility of ectopic secretion of growth hormone-releasing hormone $(\mathrm{GHRH})$ by the paraganglioma was considered and serum GHRH level requested. Subtotal resection of the mediastinal mass was undertaken and histology confirmed this to be a malignant paraganglioma. CT thorax and abdomen performed prior to postoperative radical radiotherapy revealed recurrent tumour anterior to the trachea and a previously unsuspected large mass in the head of the pancreas. IGF1 remained elevated at $36.8 \mathrm{nmol} / 1$ and the GHRH level was in excess of $4000 \mathrm{ng} / \mathrm{l}(<10-60)$. The patient completed 50 Gy of radiotherapy, in 25 fractions to the thoracic paraganglioma, and was then referred for removal of the pancreatic tumour. Whipples procedure produced clinical and near biochemical correction of his acromegaly (Table 1) with resolution of the sleep apnoea syndrome. GHRH level was slightly elevated at $65 \mathrm{ng} / \mathrm{l}$ postoperatively, abdominal CT scan showed no evidence of recurrent tumour and his most recent IGF1 is normal at 14.0 $\mathrm{nmol} / 1$.

\begin{tabular}{|r|c|c|c|l|l|l|}
\hline & \multicolumn{3}{|c|}{ Pre-operative } & \multicolumn{3}{c|}{ Post-operative } \\
\hline Time & $\begin{array}{l}\text { IGF1 } \\
\text { (mU/I) }\end{array}$ & $\begin{array}{l}\text { Glucose } \\
\text { (nmo//) })\end{array}$ & $\begin{array}{l}\text { GH } \\
\text { (mmol//) })\end{array}$ & $\begin{array}{l}\text { IGF1 } \\
\text { (mU/l) })\end{array}$ & $\begin{array}{l}\text { Glucose } \\
\text { (nmol//) }\end{array}$ & $\begin{array}{l}\text { GH } \\
\text { (mU/l) }\end{array}$ \\
\hline 0 & 44.6 & 4.5 & 9.7 & 20.9 & 4.6 & 5.0 \\
\hline 30 & & 7.8 & 8.0 & & 9.1 & 3.9 \\
\hline 60 & & 9.7 & 11.7 & & 9.3 & 3.1 \\
\hline 90 & & 10.1 & 6.1 & & 8.8 & 2.9 \\
\hline 120 & & 8.6 & 6.8 & & 5.7 & 2.6 \\
\hline
\end{tabular}

Table 1 Glucose and growth hormone response to $75 \mathrm{mg}$ glucose load preand post-resection of the pancreatic tumour

\section{OTHER INVESTIGATIONS}

MRI of the pituitary fossa demonstrated no abnormality and his full basal hormonal profile was unremarkable- [T4 (total) $137 \mathrm{nmol} / 1$ (60-160), TSH $1.3 \mathrm{mU} / \mathrm{l}(0.4-4)$, Prolactin 261 mU/l (0-450), FSH 6.6 U/l (1-10), LH 3.1 U/l (312), Testosterone $13.9 \mathrm{nmol} / \mathrm{l}$ (9.737)]. Urinary catecholamine levels postradiotherapy were normal, noradrenaline 0.04 $\mathrm{mcg} / 24$ hours $(0-0.1)$ and adrenaline $0.4 \mathrm{mcg} / 24$ hours (0-0.45).

\section{PATHOLOGY}

The biopsies and resection of the mediastinal tumour showed the typical features of a paraganglioma with well defined nests of neuroendocrine cells ("Zellballen") surrounded by a rim of cells showing immunohistochemical staining for S100 (sustentacular cells). Although predictions about the behaviour of paragangliomas are difficult to make, the presence of high mitotic rate and focal areas of necrosis pointed to a malignant course, as is the case with most endocrine and neuroendocrine tumours.

The pancreatic lesion was an endocrine tumour composed of predominantly ovoid cells forming variable-sized groups, in some areas being closely packed and simulating solid sheets of cells, and in others being separated by distinct bands of fibrous connective tissue. An immunohistochemical screen for a wide range of hormones showed staining for glucagons only, and there was no evidence of growth hormone. Staining for GHRH was not available.

\section{DISCUSSION}

Acromegaly is a rare condition with an incidence of five cases per million population. The vast majority of cases are caused by pituitary somatotrophinomas, which are usually macroadenomas due to the long lag period from onset of disease to diagnosis. Ectopic secretion of growth hormone or GHRH is uncommon, but immuno-reactive GHRH is detectable in $36 \%$ of neuroendocrine tumours, and more than $50 \%$ of small cell carcinomas of the lung in one series ${ }^{(1)}$. However, pancreatic GHRH secreting tumours causing clinical manifestations of acromegaly are extremely $\operatorname{rare}^{(2,3)}$ and there are no previous reports of an association with a non-secreting mediastinal paraganglioma. The normalisation 
of growth hormone response to glucose challenge and the significant drop in GHRH levels post-operatively provide strong circumstantial evidence that the pancreatic mass was the source of our patient's acromegaly. Further evidence is provided by the resolation of clinical manifestations of acromegaly, and in particular, correction of the presenting obstructive sleep apnoea.

Obstructive sleep apnoea is common in patients with acromegaly, being documented in $60 \%$ of cases in one large study ${ }^{(4)}$. Hypertrophy of the pharyngeal mucosa, macroglossia and/or jaw anomaly account for the prevalence of sleep apnoea in acromegaly, but central apnoea and respiratory centre control dysfunction have also been reported. There is no correlation between $\mathrm{GH}$ levels and the severity of sleep apnoea, with reports of the condition in treated patients with low or normal $\mathrm{GH}^{(5)}$. Surgical or medical treatment of acromegaly usually causes remission of sleep apnoea ${ }^{(6,7)}$. Failure to respond may relate to fixed hypertrophy and fibrosis of the pharyngeal musculature or fixed jaw anomaly. Only a handful of patients with GHRH-secreting tumours documented have gained remission of their sleep apnoea.

The potential for complete cure, and the prevention of wasted effort searching for a nonexistent pituitary tumour, makes awareness of the possibility of ectopic secretion of biologically significant amounts of GHRH clinically important. This case illustrates the necessity for full investigation of any patient in whom this diagnosis is entertained.

\section{REFERENCES}

1 Christofides ND, Stephanou A et al. Distribution of immunoreactive growth hormone-releasing hormone in the human brain and intestine and its production by tumours. J Clin Endo \& Met 1984;59(4);747-51

2 Sano T, Asa SL et al. Growth hormone-releasing hormoneproducing tumours: clinical, biochemical and morphological manifestations. Endo Reviews 1988;9(3);357-73

3 Faglia G, Arosio M et al. Ectopic acromegaly. Endo \& Met Clinics of North America 1992;21(3);575-95

4 Grunstein RR, Ho KY et al. Sleep apnoea in acromegaly Ann Int Med 1991;115:527-32

5 De Boer H, Roelfsema F et al. Plasma growth hormone profiles and sleep: a study of 13 treated patients. Clin Endo 1989;30:251-61

6 Pettani L, Polo O et al. Nocturnal breathing abnormalities in acromegaly after adenomectomy. Clin Endo 1995;43:17582

7 Buyse B, Michiels E et al. Relief of sleep apnoea after treatment of acromegaly: report of 3 cases and reviews of the literature. Eur Resp J 1997;10:1401-4 